\title{
THE EFFECT IN HUMANS OF EXTRACELLULAR PH CHANGE ON THE RELATIONSHIP BETWEEN SERUM POTASSIUM CONCENTRATION AND INTRACELLULAR POTASSIUM ${ }^{1}$
}

\author{
By JAMES M. BURNELL, MARIO F. VILLAMIL,² BEN T. UYENO, AND \\ BELDING H. SCRIBNER \\ (From the Veterans Administration Hospital and the Department of Medicine, University of
Washington School of Medicine, Seattle, Wash.)
}

(Submitted for publication March 20, 1956; accepted May 10, 1956)

For many years investigators have been aware of the association of hyperkalemia with acidosis and hypokalemia with alkalosis. The early in vitro work of Fenn and Cobb (1) suggested that there might be a cause and effect relationship. However, it was not until recently that satisfactory in vivo data were obtained (2-7) which permitted the formulation of the hypothesis that changes in extracellular $\mathrm{pH}$ altered the extracellular potassium concentration independently of changes in total body potassium ${ }^{3}(7)$. Thus, in animals, acidosis increases and alkalosis decreases the serum potassium concentration independently of changes in total body potassium. The present study demonstrates similar interrelationships in humans.

\section{EXPERIMENTAL PLAN AND METHODS}

Five patients were selected for study because of alterations of extracellular $\mathrm{pH}$ of either metabolic or respiratory origin. During the nine periods of study (five in the same patient) an attempt was made to change extracellular $\mathrm{pH}$ rapidly and observe the effect of this change on the serum potassium concentration. Extracellular $\mathrm{pH}$ was changed by appropriate therapy which included infusions of isotonic mixtures of $\mathrm{NaCl}, \mathrm{HCl}$, $\mathrm{NH}_{4} \mathrm{Cl}, \mathrm{NaHCO}_{3}$ and sodium lactate. In one patient eight per cent $\mathrm{CO}_{2}$ inhalation was used in combination with $\mathrm{HCl}$ infusion. In order to control the effect of changes in total body potassium on the serum potassium concentration experimental periods were short and an attempt was made to change potassium balance only slightly

\footnotetext{
${ }^{1}$ Supported by grants from Abbott Laboratories, the National Institutes of Health (Grant No. H-2185) and the Washington State Heart Association.

${ }^{2}$ Supported as a research associate by a grant from the Schweppe Foundation.

${ }^{3}$ The effect of alterations of extracellular $\mathrm{pH}$ on the relationship between extracellular and intracellular potassium is probably related to intracellular buffering and therefore ultimately dependent upon intracellular $\mathrm{pH}$ change. However, since the latter cannot be measured, the relationship must be studied in terms of extracellular $\mathrm{pH}$.
}

and in the direction opposite to the anticipated change in the serum potassium concentration. Because the caloric needs of none of the patients had been met during the periods antecedent to the experimental period, it was presumed that glycogen stores were depleted. During the experimental periods caloric needs were not met in order that potassium not be deposited with glycogen.

During the period of $\mathrm{pH}$ change sodium, potassium, chloride and nitrogen balances were determined in the usual manner. All patients were parenterally fed and none had stools during the period of study.

Femoral venous blood samples were considered to reflect more accurately than would arterial blood samples the $\mathrm{pH}$ of the extracellular space. Whole blood $\mathrm{pH}$ was determined anaerobically within ten minutes at $38^{\circ}$ centigrade using a Cambridge $\mathrm{pH}$ meter with a glass electrode. Duplicate determinations, bracketed by standards, agreed within $0.02 \mathrm{pH}$ unit. Sodium and potassium concentrations were determined by Baird internal standard flame photometry. Duplicate potassium determinations agreed within $0.1 \mathrm{mEq}$. per $\mathrm{L}$. Chloride was determined by a modification of the Schales' mercury titration method (8). Plasma bicarbonate was determined by a modification of the Van Slyke titration (9). Serum and urine non-protein nitrogen was determined by the method of Koch and McMeekin (10).

\section{Calculations}

1. Change in the intracellular potassium content in excess of nitrogen,

where:

$$
\Delta \mathrm{K}_{\mathrm{I}}=\mathrm{bK}^{\prime}-\Delta \mathrm{K}_{\mathbf{E}}
$$

$\mathrm{bK}^{\prime}=$ Potassium balance corrected for nitrogen.

$\Delta \mathbf{K}_{\mathbf{E}}=$ Change in the extracellular potassium content.

2. Potassium balance corrected for nitrogen,

where:

$$
\mathrm{bK}^{\prime}=\mathrm{bK}-\left(3 \times \mathrm{bN}^{\prime}\right) \text {, }
$$

$\mathrm{bK}=$ Potassium balance

$3=$ Factor relating potassium balance to nitrogen balance.

$\mathrm{bN}^{\prime}=\mathrm{bN}-(\Delta \mathrm{NPN} \times \mathrm{W})$

where:

bN $=$ Nitrogen balance.

$\triangle \mathrm{NPN}=$ Change in serum non-protein nitrogen

$\mathrm{W}=$ Total body water estimated as $60 \%$ of body weight. 
3. Change in extracellular potassium content,

where :

$$
\Delta \mathrm{K}_{\mathrm{E}}=\mathrm{K}_{\mathrm{E}_{2}}-\mathrm{K}_{\mathrm{E}_{1}}
$$

$\mathrm{K}_{\mathrm{E}_{1}}=\mathrm{K}_{1} \times \mathrm{E}_{1}$

$\mathrm{K}_{\mathrm{E}_{2}}=\mathrm{K}_{2} \times \mathrm{E}_{2}$ where :

$\mathrm{K}_{1}=$ Initial potassium concentration in plasma.

$\mathrm{K}_{2}=$ Final potassium concentration in plasma.

$\mathrm{E}_{1}=$ Initial Volume of extracellular space calculated as $20 \%$ of body weight.

$\mathrm{E}_{2}=$ Final Volume of extracellular space determined from changes in the chloride space.

RESULTS

The effect of extracellular $\mathrm{pH}$ change on the serum potassium concentration is illustrated (Figure 1 ) by the course of events in patient $H$. M. This patient had at the outset respiratory alkalosis associated with hepatic coma. Extracellular $\mathrm{pH}$ was altered by a combination of $\mathrm{CO}_{2}$ inhalation and $\mathrm{HCl}$ infusion. No potassium was administered during the period of study and the cumulative potassium balance in excess of nitrogen at the end of four days was minus $63 \mathrm{mEq}$. The reciprocal relationship between extracellular $\mathrm{pH}$ and the serum potassium concentration is apparent. Also when the $\mathrm{pH}$ was normal the serum potassium concentration was normal both before and after a loss of about $50 \mathrm{mEq}$. of potassium in excess of nitrogen. This observation is in agreement with the opinion that changes of less than $100 \mathrm{mEq}$. in potassium balance have a small effect per se on the serum potassium concentration (11).

The changes in serum electrolytes and electrolyte balances during the nine periods of study in five patients are presented in Table I and the important changes are summarized in Table II. In each instance a change in extracellular $\mathrm{pH}$ was associated with an inverse change in serum potassium concentration: Changes in intracellular potassium were small and in all but one instance opposite in direction to the change in serum potassium concentration. In the last column of Table II the change in serum potassium concentration per 0.1 unit change in extracellular $\mathrm{pH}$ has been calculated for each period of study. The range for four periods of correction of acidosis was 0.50 $\mathrm{mEq}$. per $\mathrm{L}$. to $1.20 \mathrm{mEq}$. per L. change per 0.1 $\mathrm{pH}$ change. The mean was $0.68 \mathrm{mEq}$. per $\mathrm{L}$. change per $0.1 \mathrm{pH}$ change. For correction of alkalosis the range was from $0.40 \mathrm{mEq}$. per $\mathrm{L}$. to 1 $\mathrm{mEq}$. per L. change $\mathrm{pH} 0.1$ unit $\mathrm{pH}$ change. The

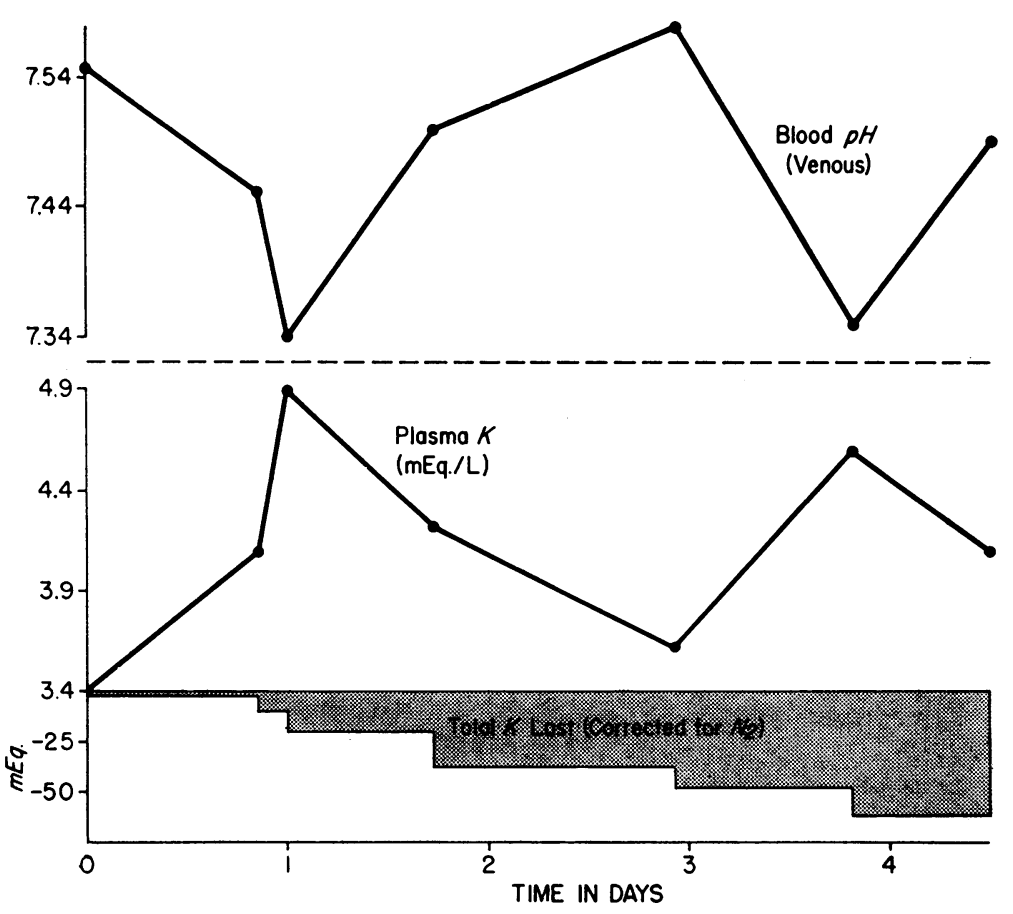

Fig. 1. Serial. Changes in Blood pH, Plasma Potassium Concentration and Potassicm Balance in Patient H. M. 
EFFECT OF EXTRACELLULAR PH ON POTASSIUM EQUILIBRIUM

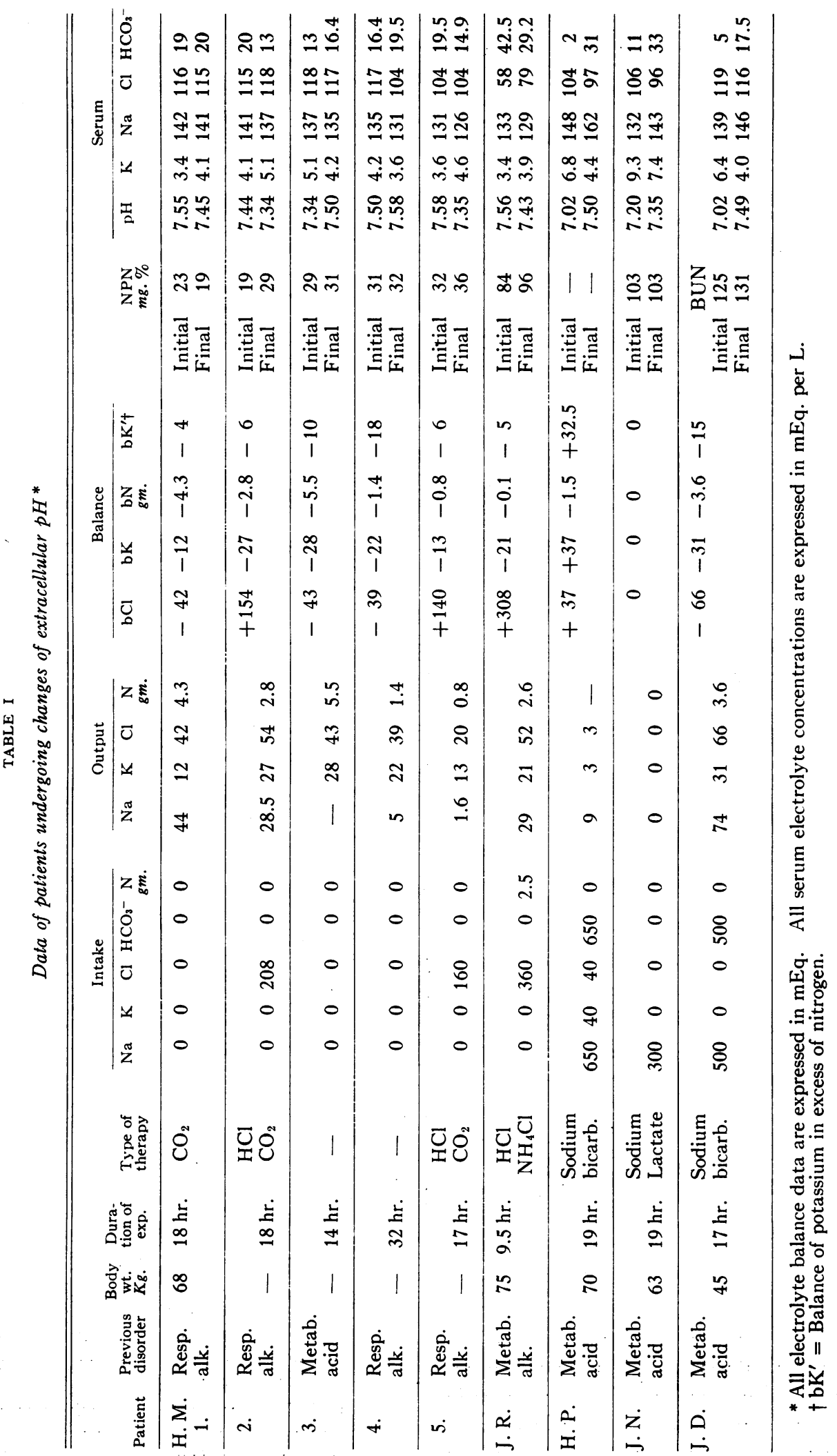


TABLE II

Relationship between changes in extracellular $p H$ and change in serum potassium concentration in nine experimental periods in five human subjects

\begin{tabular}{lccccc}
\hline Patient & Period & $\Delta \mathrm{K}_{\mathrm{s}}{ }^{*}$ & $\Delta \mathrm{pH}$ & $\Delta \mathrm{K}_{\mathrm{I}}{ }^{*}$ & $\Delta \mathrm{K}_{\mathrm{s}} / \mathbf{0 . 1} \Delta \mathrm{pH}$ \\
\hline H. M. & 1 & +0.7 & -0.10 & -13 & 0.63 \\
& 2 & +1.0 & -0.10 & -25 & 1.00 \\
& 3 & -0.9 & +0.16 & +3 & 0.56 \\
& 4 & -0.6 & +0.08 & -16 & 0.75 \\
J. R. & 5 & +1.0 & -0.23 & -25 & 0.45 \\
H. P. & 1 & +0.5 & -0.13 & -12.5 & 0.40 \\
J. N. & 1 & -2.4 & +0.48 & +60 & 0.50 \\
J. D. & 1 & -2.9 & +0.15 & +14 & 1.27 \\
& & & +0.47 & +8 & 0.51 \\
\hline
\end{tabular}

$* \Delta \mathrm{K}_{\mathrm{B}}=$ Change in the serum potassium concentration in $\mathrm{mEq}$. per $\mathrm{L}$.

$\Delta \mathrm{K}_{\mathrm{I}}=$ Change in intracellular potassium in excess of nitrogen.

mean was $0.58 \mathrm{mEq}$. per L. change per $0.1 \mathrm{pH}$ change. The mean for both groups was 0.63 $\mathrm{mEq}$. per L. change in serum potassium concentration per 0.1 unit change in extracellular $\mathrm{pH}$.

\section{DISCUSSION}

There are several problems inherent in attempts to quantitate the relationship between extracellular $\mathrm{pH}$ change and change in the serum potassium concentration. First, metabolic as compared with respiratory $\mathrm{pH}$ alterations may involve different intracellular buffering mechanisms and thus be quantitatively different. In these studies no effort was made to separate metabolic and respiratory disorders of extracellular $\mathrm{pH}$. Second, changes in the serum potassium concentration induced by changes in total body potassium or changes in glycogen stores introduce additional variables. Difficulty in control of these variables may account for the wide range of $\mathrm{pH}$ induced change in the serum potassium concentration reported here.

In these studies changes in intracellular potassium in excess of nitrogen were in the opposite direction as the change in serum potassium concentration. Thus, the change in serum potassium concentration attributed to change in extracellular $\mathrm{pH}$ in most instances might be slightly greater than that recorded.

The results demonstrate consistently that acidosis increases and alkalosis decreases the serum potassium concentration independently of changes in total body potassium. As discussed elsewhere (7), the human muscle analyses of Mudge and
Vislocky (12) offer further support for the validity of this interrelationship.

Demonstration of this interrelationship between the serum potassium concentration and extracellular $\mathrm{pH}$ has several important clinical implications :

1) If the effect of $\mathrm{pH}$ is considered when interpreting the serum potassium concentration as an index of potassium need, this concentration becomes a more accurate guide to potassium therapy (11).

2) Extracellular $\mathrm{pH}$ must be controlled during experimental evaluation of other factors considered to influence the serum potassium concentration.

3) In the management of acute renal failure correction of acidosis and production of alkalosis will lower the serum potassium concentration and may facilitate prevention of potassium intoxication (cases H. P. and J. N.).

\section{SUMMARY AND CONCLUSIONS}

1. The effect of extracellular $\mathrm{pH}$ change on the relationship between the serum potassium concentration and intracellular potassium has been studied in 5 patients. A total of 9 experimental periods is described.

2. The results confirm the hypothesis that acidosis increases and alkalosis decreases the serum potassium concentration independently of changes in intracellular potassium. For every 0.1 unit change in extracellular $\mathrm{pH}$ there was an average inverse change of $0.6 \mathrm{mEq}$. per $\mathrm{L}$. in the serum potassium concentration.

\section{ACKNOWLEDGMENT}

The authors are grateful to Miss Margaret Brown, Miss Marjorie Ferguson, Miss Patricia Hoover, and Miss Elma Lile for technical assistance.

\section{REFERENCES}

1. Fenn, W. O., and Cobb, D. M., The potassium equilibrium in muscle. J. Gen. Physiol., 1934, 17, 629.

2. Keating, R. E., Weichselbaum, T. E., Alanis, M., Margraf, H. W., and Elman, R., The movement of potassium during experimental acidosis and alkalosis in the nephrectomized dog. Surg. Gynec. \& Obst., 1953, 96, 323.

3. Pitts, R. F., Mechanisms for stabilizing the alkaline reserves of the body. Harvey Lectures 1952-53, New York, Academic Press, 1954, p. 172. 
4. Swan, R. C., and Pitts, R. F., Neutralization of infused acid by nephrectomized dogs. J. Clin. Invest., 1955, 34, 205.

5. Giebisch, G., Berber, L., and Pitts, R. F., the extrarenal response to acute acid-base disturbances of respiratory origin. J. Clin. Invest., 1955, 34, 231.

6. Stanbury, S. W., and Thomson, A. E., The renal response to respiratory alkalosis. Clin. Sc., 1952, $11,357$.

7. Scribner, B. H., Fremont-Smith, K., and Burnell, J. M., The effect of acute respiratory acidosis on the internal equilibrium of potassium. J. Clin. Invest., 1955, 34, 1276.

8. Scribner, B. H., Bedside determination of chloride: A method for plasma, urine and other fluids and its application to fluid balance problems. Proc. Staff Meet., Mayo Clin., 1950, 25, 209.

9. Scribner, B. H., and Cailluoette, J. C., Improved method for the bed-side determination of bicarbonate in serum. J. A. M. A., 1954, 155, 644.

10. Koch, F. C., and McMeekin, T. L., A new direct nesslerization micro-Kjeldahl method and a modification of the Nessler-Folin reagent for ammonia. J. Am. Chem. Soc., 1924, 46, 2066.

11. Scribner, B. H., and Burnell, J. M., Interpretation of the serum potassium concentration. Metabolism, In press.

12. Mudge, G. H., and Vislocky, K., Electrolyte changes in human striated muscle in acidosis and alkalosis. J. Clin. Invest., 1949, 28, 482.

\section{SPECIAL NOTICE TO SUBSCRIBERS}

Post Offices will no longer forward the Journal when you move.

Please notify The Journal of Clinical Investigation, Business Office, 622 West 168th Street, New York 32, N. Y. at once when you have a change of address, and do not omit the zone number if there is one. 